\title{
Da Posse e seus efeitos
}

\section{Octavio M. Guimarües}

O trabalho intitulado "Da Posse e seus efeitos", premiado pelo Instituto da Ordem dos Advogados Brasileiros, do Rio de Janeiro, sofreu divergência num ou noutro ponto quanto a certos conceitos que se expenderam.

Expor-se-ão agora as objeções principais que se fizeram e em seguida dar-se-ão as razões que determinaram as asserções incriminadas.

Certamente os contraditores não se aterão ainda à exposição, mas êsse não é nem poderia ser o intento do expositor, que se restringe tão-só à explicação do que se escreveu, estadeando os motivos por que foi assim que se precisaram as idéias contrariadas.

$10^{\circ}$ - Objetou-se relativamente à extensão da posse, pois o autor reduziu sua aplicação aos direitos reais. Tal restrição não é justificável, asseveram os arguentes, por vários motivos, entre os quais se assinalam os seguintes: o art. 485 do Código Civil considerou como possuidor não só quem tem poderes inerentes ao domínio, como também aquêle que tem poderes inerentes à propriedade, pois é por essa dualidade de vocábulos que a lei se exprime.

$\mathrm{E}$ é corrente que o vocábulo propriedade possui uma compreensão mais extensa do que o vocábulo domínio, pois ao passo que êste se limita às coisas corpóreas suscetíveis de apropriação, aquêle se distende, abrangendo também os direitos pessoais. 
Tal entendimento, todavia, não procede, pois que ambas essas expressões estão valendo aí como sinônimas, representando as duas uma só idéia, isto é, o conceito de que a posse incide sòmente sôbre os direitos reais, plenos ou não.

Que foi êsse o entendimento da lei se verifica pelo confronto do artigo acima referido com as demais disposições subsequentes, notadamente com a designada no art. 530. Aí a lei se refere à aquisição da propriedade imóvel e indica os vários modos que legitimam êsse ato, designando todos êles a aquisição do domínio, como a transcrição, a acessão e o usucapião.

Denominou-se assim, como propriedade aquilo que deveria ser indicado mais expressivamente como domínio, confundindo a lei as duas expressôes, como se ambas exprimissem a mesma idéia.

Acrescentam ainda os opositores que a aquisição da posse se opera também "pelo exercício do direito", como dispõe o art. 493, n. I, do Código Civil, não sendo lícito distinguir quando a lei não distinguiu.

Referindo-se a direitos sem especificar a sua natureza, deve o intérprete atribuir ao têrmo que se empregou tôda a sua amplitude, sendo pois incivil a interpretação que restringe o preceito irrestrito.

Essa argumentação também não se justifica; é mais enganosa do que exata. A lei deve ser interpretada dentro do sistema que a envolve, supondo-se sempre que as regras posteriores hão de se entrozar nas anteriores, harmonizando-se com elas.

Valendo a posse como uma detenção física, ou como um ato material sôbre coisas corpóreas e apropriáveis, há de se entender daí em diante que os preceitos seguintes terão que se ater ou de se ligar a essa concepção originária. $\mathrm{E}$ portanto deve o intérprete concluir que referindo-se a lei ao exercicio do direito, quer referir-se exclusivamente ao exercício do direito real, a saber ao exercício do direito que recái sôbre coisas corpóreas, como o direito ao domínio, a servidão, ao usufruto, etc.. 
Alèm disso é certo que a turbação parcial ou total semanifesta por atos materiais, e pois com ofensa a direitos. corpóreos ou de conteúdo material, que são os únicos sujeitos à agressão dessa natureza.

$2 .^{\circ}$ - Conforme a teoria de Ihering adotada pelo Código Civil Brasileiro, prescindiu-se do animus sibi habendi para existência da posse.

É bastante que haja o corpus, ou a detenção física pelo exercício pleno ou não dos direitos inerentes ao domínio, para que se caracterize o ius possessionis. Quem detem e explora ou se utiliza econômicamente da coisa detida, a êsse é a quem a lei considera como possuidor. $E$ não é mister assim a indagação subjetiva ou do animus mediante o qual se exercem os atos materiais.

Entretanto, sendo pacífica essa tese, desertou-se dêsse princípio, nomeando-se a posse exercida com o animus de dono e mais ainda com a opinio domini.

A arguição há de decorrer de um exame desatento do que se escreveu. Pois aí se indicou a posse de duas naturezas, seja a posse justa, seja a posse de bôa-fé, a primeira isenta do animus domini e a segunda reclamando para sua efetivação a opinio domini.

A posse é justa quando não é nem violenta, nem clandestina, nem precária, como dispõe o art. 489 do Código Civil.

'Para que a posse seja considerada como justa é mistér primeiramente que ela não advenha de atos violentos. É necessário também que não seja clandestina, ou que se manifeste ostensivamente, para que o titular do direito prejudicado possa desfazer a situação irregular assim que conheça a ofensa do seu direito.

Também tem que ser uma posse isenta de precariedade; isto é, não provinda de uma relação jurídica mediante a qual o possuidor reconhece o direito alheio.

Possuindo êsses requisitos de posse pacífica, de posse pública e de posse não precária e nem equívoca, então essa 
posse ter-se-á como justa, outorgando ao possuidor, o iús possessionis, com os efeitos que defluem dêsse direito.

São efeitos civis da posse justa: - a proteção possessória, pelos interditos, e também a transmudação do iús possessionis em iús possidendi, quando a posse perdurar dez anos quanto às coisas móveis, e trinta anos quanto aos imóveis.

São êsses os únicos efeitos da posse embora exercida sem o ânimo de dono.

É possível que se acresça à posse justa o desconhecimento do obstáculo ou do vício que impedem a aquisição. Então nessa hipótese é necessário que o possuidor exerca os poderes plenos ou não inerentes ao seu direito com a opinião de que é dono. Essa crença fundada em fatos objetivos, ou advinda de êrro excusável, é que manifesta a posse de bôa-fé. $O$ possuidor adquire com a intenção de realizar um ato definitivo, ignorando os defeitos que contaminam o seu direito.

Essa situação de ignorância justificável é que atribui resultados jurídicos a atos que normalmente deveriam ser ineficazes, como a aquisição a non domino ou por ato nulo. Tais atos não deveriam produzir nenhum resultado jurídico; entretanto a lei outorgou consequências jurídicas a êsses atos ineficientes, em virtude da bôa-fé do possuidor.

Deu-se ao possuidor em tal caso direito aos frutos, indenização das benfeitorias e também o direito à aquisição do domínio pelo usucapião ordinário, quando se ajuntar o justo titulo à posse de bôa-fé.

Não houve assim discrepância alguma quando se aludiu num caso à posse desprovida do animus, e noutro caso ̀̀ posse de bôa-fé em que o animus domini é elemento essencial.

$3 .^{\circ}$ - Alegou-se por fim a impossibilidade da reintegração preliminar que se insinuou, quando a posse tivesse sido ofendida por outra maneira que rão a violência física. 
Sòmente a ação por meios materiais ou a ofensa mediante atos de fôrça, exclusivamente essa é que possibilitaria a reintegração liminar.

Assim, a falta da restituição da coisa estatuáda por convenção, tal transgressão do direito do possuidor não poderia ser defendida pelo recurso extremo da reintegração imediata.

Sustentou-se, todavia, tese diferente, afirmando-se que na hipótese da extinção da relação jurídica, de pleno direito, daí por diante a posse não teria nenhum título que a legitimasse e, por identidade de razão, deveria o ato da recusa ser equiparado à violência, sujeitos assim ambos os casos a tratamento igual.

O locatário, por exemplo, cujo direito à locação se findou de pleno direito, deveria, conforme o contrato, restituir desde logo a coisa alheia.

E não restituindo, sua posse até então legítima se transformaria em detenção ilícita, em cujo caso deveria a lei outorgar so locador o direito de reingressar desde logo na sua posse anterior.

Pois é certo que, nesses casos de relação jurídica, o contratante beneficiado está exercendo diretamente a posse sôbre a coisa alheia, subordinado o seu ao direito de onde proveio.

Extinta a posse derivada, desde então a posse originária há de recuperar a sua posição primitiva, desde que no contrato se estatuiu a terminação de pleno direito ou pelo só transcurso do prazo.

Essa interpretação não é extravagante, ou desconforme à lógica jurídica, por estas razões que mais se sumariam do que se desenvolvem.

$\mathrm{O}$ art. 490 do Cód. Civil declara que o possuidor tem direito a ser restituído no caso de esbulho. E o esbulho, como a turbação, pode manifestar-se por ação, quando se praticam atos materiais na coisa alheia e por omissão quando se impede que o possuidor exerça parcial ou totalmente a sua posse. 
Assim, não tendo a lei qualificado a natureza do esbu-lho, pode êle ser também caracterizado por omissão, quando o possuidor direto obsta a recuperação.

$O$ vocábulo violência não quer significar ùnicamente $O$ emprêgo de ato material, pela fôrça ou pelas armas, mas pode também significar a intensidade da transgressão, qual o que sucede quanto à palavra violência em relação à intensidade do calor ou do fogo.

Êsse sentido translato consignado nos dicionários da língua, imputou ao vocábulo em questão ambos êsses dois sentidos; e assim é justificável a equiparação da violência física à violência moral, ou ao ato que contradiz a vontade do possuidor.

Seja entretanto como fôr, o que é certo que ambas essas. transgressões, daquele que violenta pela fôrça a posse alheia e daquele que também viola a posse do seu parceiro no contrato, recusando a restituição, são tôdas as duas idênticas na sua ilicitude e uniformes na contrariedade à vontade do prejudicado.

Situações que se assemelham, hão de ter idêntica defesci pelo mesmo processo possessório. 